\title{
Impact of heartburn and regurgitation on individuals' well-being in the general population: a Brazilian national survey
}

\author{
Joaquim Prado P MORAES-FILH0 ${ }^{1}$, Gerson DOMINGUES ${ }^{2}$, Decio CHINZON ${ }^{1}$, \\ Fabiana ROVEDA ${ }^{3}$, Abner Augusto LOBÃO NETO ${ }^{3}$ and Schlioma ZATERKA ${ }^{1}$
}

Received: 30 March 2020 Accepted: 9 October 2020

\begin{abstract}
Background - Heartburn and acid regurgitation are typical symptoms usually associated with gastroesophageal reflux disease (GERD). GERD is one of the gastrointestinal diagnosis with higher prevalence worldwide, significantly impairing patients' quality of life. Objective-The objective of this study was to analyze the impact of GERD-related symptoms in the Brazilian urban population. Methods - National telephone survey with community-dwelling Brazilian individuals. Self-reported prevalence and frequency of symptoms (heartburn / regurgitation) were assessed. Individuals rated the impact of symptoms in their general well-being using a numeric scale from 1 to $10(1=$ no impact; $10=$ very intense, preventing the person to eat and perform daily routine activities). Descriptive and bivariate statistical analyses were performed. Results - The final sample was comprised of 1,773 subjects, $935(52.7 \%)$ females, an average of 40 years old. The prevalence of heartburn and regurgitation in the past 6 months was $26.2 \%$ ( $=466$ ) and $11.0 \%(n=196)$, respectively. Women presented higher prevalence (heartburn $n=266,28.5 \%$ and regurgitation $n=119,12.7 \%)$ than men $(n=200$, $23.1 \%$ and $\mathrm{n}=78,8.9 \%$, respectively) $(P<0.05)$. Heartburn in the past week was reported by 175 individuals $(9.8 \%)$, while regurgitation episodes by 67 $(3.8 \%)$. Absence of impact of the symptom in the overall well-being was observed for 82 subjects $(17.6 \%)$ with heartburn and 18 individuals $(9.2 \%)$ with regurgitation. Very intense impact was reported by 46 subjects $(9.8 \%)$ with heartburn and $41(20.9 \%)$ with regurgitation. Women's well-being was more affected than men's (mean score 5.45 vs $4.71, P<0.05$ ). Conclusion - Heartburn and regurgitation were frequent symptoms, women with higher prevalence. These symptoms led to a substantial impact on individuals' well-being, women being more affected.
\end{abstract}

HEADINGS - Gastroesophageal reflux. Heartburn. Quality of life. Prevalence. Signs and symptoms. Surveys and questionnaires.

\section{INTRODUCTION}

Heartburn and regurgitation are typical symptoms associated with gastroesophageal reflux disease (GERD), although heartburn may also be observed in patients with functional heartburn ${ }^{(1)}$. GERD is one of the gastrointestinal diagnosis with higher prevalence worldwide, significantly impairing patients' acid related quality of life (HRQL) ${ }^{(2-4)}$. A national survey conducted in the United States with over 71,000 community-dwelling individuals observed that $61 \%$ reported $\geq 1$ gastrointestinal symptom in the past week and heartburn and reflux were the most frequent selfreported symptoms $(30.9 \%)^{(5)}$.

In Brazil, a national survey interviewing 13,959 urban individuals identified an overall heartburn prevalence of $11.9 \%$, at least once a week heartburn occurrence of $4.6 \%$ and GERD diagnosis in $7.3 \%{ }^{(6)}$. Another Brazilian population-based survey observed that GERD symptoms were negatively associated with individuals' psychological well-being. After controlling for confounders, the odds of having GERD symptoms in the study was 2.14 times higher among those individuals self-assessing their psychological well-being as low as compared to those rating as high ${ }^{(7)}$. Thus, depending on the intensity and frequency of heartburn and regurgitation, the well-being and consequently the quality of life, may be significantly impaired.

The objective of the present study was to evaluate the impact of heartburn and regurgitation on the well-being of Brazilian individuals from a general urban population sample.

\section{METHODS}

A cross-sectional analysis of data was performed from a national telephone survey that aimed to determine the prevalence and distribution of gastrointestinal (GI) symptoms in communitydwelling Brazilian individuals.

The survey was conducted from August 6th to September 12th, 2018. A sample of 1800 adults, 18-69 years, was recruited from an already existing nationwide panel of individuals who take regular part in opinion and market research surveys. Sampling from the panel was conducted using quotas to represent the regions of the country. Sampled individuals were contacted by telephone and in-

Declared conflict of interest of all authors: Moraes-Filho JPP: speaker for Takeda. Domingues G: speaker for Takeda and Hypera. Chinzon D: advisory board member for Takeda and Hypera. Roveda F: medical manager at Takeda at the time of the study. Lobão Neto AA: medical director at Takeda. Zaterka S: advisory board member for Takeda and Ache; speaker for EMS and Takeda. Disclosure of funding: The study was supported by Takeda Pharmaceuticals Brazil.

Universidade de São Paulo, Faculdade de Medicina, Departamento de Gastroenterologia, São Paulo, SP, Brasil. ${ }^{2}$ Universidade do Estado do Rio de Janeiro, Faculdade de Medicina, Departamento de Gastroenterologia, Rio de Janeiro, RJ, Brasil. ${ }^{3}$ Takeda Pharmaceuticals - Brasil.

Corresponding author: Joaquim Prado P Moraes Filho. E-mail: joaquim.prado@usp.br 
vited to participate in the survey. After receiving information about study procedures and agreeing in participating, subjects were presented with questions about their demographic and socioeconomic status. Socioeconomic status was assessed using the 2015 Brazilian Criteria for Economic Classification ${ }^{(8)}$, which categorizes into three socioeconomic groups: A (higher socioeconomic status, with higher estimated income and educational level); $\mathrm{B}$ (intermediate); and $\mathrm{C}$ (lower socioeconomic status) $^{(8)}$.

Symptoms prevalence was assessed using the following questions: (i) Have you had symptoms of heartburn and/or acid regurgitation in the last 6 months?; (ii) If yes, how many times did you have these symptoms in last 6 months?; (iii) When was the last time do you remember having these symptoms? Additionally, individuals were asked to rate the impact of the symptoms in their general well-being using a numeric scale from 1 to $10(1=$ no impact; $10=$ very severe, preventing the person to eat or perform daily activities). Impact on well-being was assessed in individual levels from no impact (1) to very severe impact (10) and also in three impact levels. The following cut-offs were adopted to classify subjects according to the level of impact in general well-being:

- mild impact (1-3);

- moderate impact (4-7);

- severe impact (8-10).

This study was based on results of an opinion survey, thus no approval was required from a Research Ethics Committee. Likewise, it was not necessary to sign an Informed Consent Form. However, all procedures performed are governed by Ethical Standards of the Brazilian Association of Research Companies (ABEP) and of the European Society of Market Research (ESOMAR), in compliance with the International Standard for Quality on Market and Opinion Research - ISO 20252:2006 and the International Standard for Quality Management ISO 9001:2000.

\section{Outcomes}

The primary outcomes were the prevalence of heartburn and acid regurgitation (composite outcome) and the self-reported impact of these symptoms on individuals' general well-being. Among those who reported these GI symptoms, the average number of times they experienced symptoms in the past 6 months were also investigated as the proportion of respondents reporting these symptoms in the past week. The symptom severity in terms of well-being impairment were the secondary outcomes.

\section{Statistical analyses}

All statistical analyses were performed in SPSS (IBM SPSS Statistics for Windows Released 2015, Version 23.0. Armonk, NY: IBM Corp.). A two-tailed $P$-value of less than 0.05 was considered statistically significant. In bivariate analyses, categorical variables were compared using independent Z-test and continuous variables were explored using independent $t$-test.

\section{RESULTS}

The final sample was comprised of 1,773 subjects, $935(52.7 \%)$ women, average of 40 years old. Socio-demographic sample characteristics are presented in TABLE 1.

TABLE 2 presents the findings on heartburn and regurgitation prevalence in the total sample and according to socio-demographic characteristics. Women had a significantly higher prevalence of heartburn $(n=266,28.5 \%$ vs $n=200,23.7 \%)$ and regurgitation
TABLE 1. Sample characteristics.

\begin{tabular}{llll}
\hline \multicolumn{1}{c}{ Characteristics } & N & \multicolumn{1}{c}{$\%$} \\
\hline Age & $18-24$ years & 292 & 16 \\
$25-34$ years & 411 & 23 \\
$35-44$ years & 395 & 22 \\
45-54 years & 347 & 19 \\
$55-69$ years & 355 & 20 \\
[Mean] & 40.0 & \\
& & \\
Female & 865 & 48 \\
Male & 935 & 52 \\
Geographic region & & \\
North & 144 & 8 \\
Northeast & 477 & 27 \\
Midwest & 138 & 8 \\
Southeast & 777 & 43 \\
South & 265 & 15 \\
Brazilian criteria for socio-economic classification & & \\
Class A & 67 & 4 \\
Class B & 512 & 28 \\
Class C & 1220 & 68 \\
Brazilian Public Healthcare System & 1083 & 60 \\
Private insurance or similar & 505 & 28 \\
Out-of-pocket & 194 & 11 \\
Other source & 18 & 1 \\
\hline
\end{tabular}

TABLE 2. Prevalence of heartburn and regurgitation in the past 6 months by socio-demographic characteristics.

\begin{tabular}{|c|c|c|c|c|}
\hline \multirow{2}{*}{ Characteristics } & \multicolumn{2}{|c|}{ Heartburn } & \multicolumn{2}{|c|}{ Regurgitation } \\
\hline & $\mathbf{N}$ & $\%$ & $\mathbf{N}$ & $\%$ \\
\hline Total sample & 466 & 26.2 & 196 & 11.0 \\
\hline \multicolumn{5}{|l|}{ Age } \\
\hline $18-24$ years $(\mathrm{n}=285)$ & 69 & 24.2 & 29 & 10.2 \\
\hline $25-34$ years $(n=416)$ & 106 & 25.4 & 38 & 9.1 \\
\hline $35-44$ years $(n=397)$ & 110 & 27.7 & 43 & 10.8 \\
\hline $45-54$ years $(n=337)$ & 89 & 26.4 & 39 & 11.6 \\
\hline $55-69$ years $(\mathrm{n}=338)$ & 93 & 27.5 & 47 & 13.9 \\
\hline \multicolumn{5}{|l|}{ Sex* } \\
\hline Female $(\mathrm{n}=931)$ & 266 & 28.5 & 119 & 12.8 \\
\hline Male $(\mathrm{n}=842)$ & 200 & 23.7 & 78 & 9.3 \\
\hline \multicolumn{5}{|l|}{ Geographic region } \\
\hline North $(\mathrm{n}=136)$ & 32 & 23.5 & 14 & 10.3 \\
\hline Northeast $(\mathrm{n}=470)$ & 119 & 25.3 & 54 & 11.5 \\
\hline Midwest $(\mathrm{n}=136)$ & 32 & 23.5 & 16 & 11.8 \\
\hline Southeast $(\mathrm{n}=765)$ & 224 & 29.3 & 83 & 10.8 \\
\hline South $(n=266)$ & 59 & 22.2 & 29 & 10.9 \\
\hline \multicolumn{5}{|c|}{ Brazilian criteria for socio-economic classification } \\
\hline$A(n=194)$ & 57 & 29.4 & 26 & 13.4 \\
\hline$B(n=425)$ & 114 & 26.8 & 52 & 12.2 \\
\hline$C(n=1154)$ & 296 & 25.6 & 118 & 10.2 \\
\hline
\end{tabular}

*Statistically significant differences for both symptoms frequency. 
$(\mathrm{n}=119,12.7 \%$ vs $\mathrm{n}=78,8.9 \%)$. Other variables (age, geographic region, and socioeconomic status) were not significant $(P>0.05)$.

Among those who reported each symptom, the average number of episodes that individuals had heartburn and regurgitation in the past 6 months was 7.74 and 9.62, respectively. Bivariate analysis did not indicate statistically significant differences for this outcome by age or sex.

Regarding the association of other variables (with average number of heartburn and regurgitation episodes in the previous 6 months) subjects classified in the $\mathrm{C}$ socio-economic category (lower income group) $^{(8)}$ had significantly higher mean number of regurgitation episodes (10.7 times/6 months) than subjects from the B category (7.43). The difference versus subjects in the A category (higher income group) did not reach statistical significance ( 9.10 times/ 6 months, $P>0.05$ ). The average number of heartburn episodes was not associated with socio-economic categories $(P>0.05)$.

Heartburn in the past week was reported by 175 respondents ( $9.8 \%$ of the total sample), while regurgitation episodes occurred in the past week by 67 individuals $(3.8 \%)$. (TABLE 3$)$. Women had statistically significant higher prevalence of heartburn $(n=115$, $12.3 \%$ vs. $n=60,7.1 \%$ ). Age and sex covariates were not associated with regurgitation frequency.

TABLE 3. Prevalence of heartburn and regurgitation in the past week by age group and sex (total sample).

\begin{tabular}{|c|c|c|c|c|}
\hline \multirow{2}{*}{ Characteristics } & \multicolumn{2}{|c|}{ Heartburn } & \multicolumn{2}{|c|}{ Regurgitation } \\
\hline & $\mathbf{N}$ & $\%$ & $\mathbf{N}$ & $\%$ \\
\hline Any time in the past 6 months & 466 & 26.2 & 196 & 11.0 \\
\hline In the past week & 175 & 9.8 & 67 & 3.8 \\
\hline \multicolumn{5}{|l|}{ Age } \\
\hline $18-24$ years $(n=285)$ & 30 & 10.6 & 12 & 4.2 \\
\hline $25-34$ years $(n=416)$ & 47 & 11.3 & 13 & 3.1 \\
\hline $35-44$ years $(n=397)$ & 41 & 10.3 & 16 & 4.0 \\
\hline $45-54$ years $(n=337)$ & 25 & 7.4 & 11 & 3.2 \\
\hline $55-69$ years $(n=338)$ & 33 & 9.8 & 15 & 4.4 \\
\hline \multicolumn{5}{|l|}{ Sex } \\
\hline Female $(\mathrm{n}=931)$ & 115 & $12.3 *$ & 46 & 4.9 \\
\hline Male $(n=842)$ & 60 & 7.1 & 21 & 2.5 \\
\hline
\end{tabular}

*Statistically significant difference between men and women (heartburn only).

The self-reported impact of heartburn and regurgitation in subjects' well-being is presented in TABLE 4. Absence of impact of the symptom in the overall well-being was observed in $82(17.6 \%)$ individuals with heartburn and $18(9.2 \%)$ of individuals with regurgitation. Very severe impact was reported by $9.8 \%(n=46)$ of individuals with heartburn and $20.9 \%(n=41)$ with regurgitation. A similar pattern was observed for the predefined levels of impact (mild, moderate, and severe) with a higher impact associated more with regurgitation than with heartburn. Women had a lower proportion of "no impact" answers ( $n=39,14.5 \%$ vs $n=43,21.7 \%$, $P<0.05)$ for heartburn and a higher proportion of very severe impact (impairing ability to eat or perform daily activities) for both heartburn $(\mathrm{n}=35,13.2 \% \mathrm{vs} \mathrm{n}=11,5.5 \%, P<0.05)$ and regurgitation $(\mathrm{n}=31,26.1 \%$ vs $\mathrm{n}=9,11.5 \%, P<0.05)$. Age groups comparison $\mathrm{did}$ not reach statistical significance for this outcome.
TABLE 4. Impact of heartburn and regurgitation in individuals' well-being.

\begin{tabular}{|c|c|c|c|c|}
\hline & \multicolumn{2}{|c|}{$\begin{array}{l}\text { Heartburn } \\
(\mathrm{n}=466)\end{array}$} & \multicolumn{2}{|c|}{$\begin{array}{l}\text { Regurgitation } \\
(\mathrm{n}=196)\end{array}$} \\
\hline & $\mathbf{N}$ & $\%$ & $\mathbf{N}$ & $\%$ \\
\hline $\begin{array}{l}\text { No impact in individuals' well-being } \\
(\text { score }=1)\end{array}$ & 82 & 17.6 & 18 & 9.2 \\
\hline $\begin{array}{l}\text { Very severe impact impairing ability } \\
\text { to eat or perform daily activities } \\
(\text { score }=10)\end{array}$ & 46 & 9.8 & 41 & 20.9 \\
\hline \multicolumn{5}{|l|}{$\begin{array}{l}\text { Pre-defined levels of impact in } \\
\text { individuals' well-being }\end{array}$} \\
\hline Mild (score $=1-3$ ) & 147 & 31.5 & 43 & 21.9 \\
\hline Moderate $($ score $=4-7)$ & 192 & 42.5 & 72 & 36.7 \\
\hline Severe $($ score $=8-10)$ & 120 & 25.7 & 83 & 42.3 \\
\hline $\begin{array}{l}\text { Average score of impact in well-being } \\
- \text { mean (min-max) }\end{array}$ & \multicolumn{2}{|c|}{$5.18(1-10)$} & \multicolumn{2}{|c|}{$6.28(1-10)$} \\
\hline
\end{tabular}

\section{DISCUSSION}

In the present study it was investigated a large sample of community-dwelling individuals to assess the prevalence and impact of heartburn and regurgitation symptoms in subject's general well-being. Although not representative of all Brazilian population, the results were representative of an important sector of the urban population represented by community-dwelling individuals, in terms of sex, age, geographic region and socioeconomic status. The type of financing for healthcare services, with most individuals reported attending the National Public Healthcare System and being in the lower income group. The socio-economic criteria adopted in the study ${ }^{(8)}$ also considered educational level, increasing the likelihood that individuals answering the survey were also similar to the general population regarding this particular variable. A questionnaire for evaluation of well-being not previously validated was used because of possible variables by telephone interviews.

The overall prevalence of heartburn and regurgitation was $26.2 \%$ and $11.0 \%$ respectively, with women having a higher frequency of both symptoms. In the previous Brazilian studies different methodologies were used as well as the outcome definitions, hindering our ability to compare findings ${ }^{(6,7)}$. A Brazilian study from 2005 observed a global prevalence of heartburn of $11.9 \%$, pooling the prevalence of individuals reporting heartburn once a week $(4.6 \%)$ and those with heartburn more than once a week $(7.3 \%)^{(6)}$. Our findings indicate a self-reported frequency of heartburn in the past week of $9.8 \%$, compatible to the mentioned study, but the outcome definition was different in terms of timing. Another study surveyed individuals using a GERD definition of heartburn at least once a week for the past 12 months and a psychological well-being assessment using a visual analogue scale ${ }^{(7)}$. Authors observed a prevalence of GERD in the past year of $31.3 \%$, significantly associated with impaired psychological well-being. In the present sample, self-reported regurgitation symptoms have a higher impact in individuals' well-being than heartburn and this adverse effect is even more pronounced among women. These studies also observed that women were more affected than men by symptoms attributed to GERD, consistent with our findings and also with results from other contexts ${ }^{(6,7,9)}$.

The main limitation of our study was the recall bias risk, since 
prevalence of symptoms was self-reported and we adopted a 6 months recall period. Another limitation is related to its crosssectional approach, limiting the ability to understand longitudinal patterns of symptoms occurrence. As GERD prevalence studies usually adopt weekly frequency of heartburn and regurgitation in the past year as diagnosis definition ${ }^{(10)}$, our findings cannot be directly compared to observational data from previous studies. Taking into consideration the limitations of the present study in terms of observation of a specific populational sample, even so the findings unambiguously confirm the impairment on quality of life in individuals with heartburn/regurgitation.

Future studies may improve the understanding about GERDrelated symptoms impact in individuals' quality of life using validated questionnaires and also other patient-reported outcomes such as productivity losses.

\section{CONCLUSION}

Heartburn and regurgitation were respectively present in $26.2 \%$ and $11.0 \%$ in the studied sample of the Brazilian population. Absence of impact of the symptoms in the overall well-being was observed in $17.6 \%$ and $9.2 \%$ of individuals with heartburn and regurgitation respectively.

\section{ACKNOWLEDGEMENTS}

The authors thank Maíra Takemoto of ANOVA Health Consulting Group for providing medical writing support and editorial support, which was funded by Takeda Pharmaceuticals, São Paulo, Brazil in accordance with Good Publication Practice (GPP3) guidelines.

\section{Authors' contribution}

Moraes-Filho JPP: acquisition, analysis, or interpretation of data for the work; revising it critically for important intellectual content; final approval of the version to be published; agreement to be accountable for all aspects of the work in ensuring that questions related to the accuracy or integrity of any part of the work are appropriately investigated and resolved.
Domingues G: acquisition, analysis, or interpretation of data for the work; revising it critically for important intellectual content; final approval of the version to be published; agreement to be accountable for all aspects of the work in ensuring that questions related to the accuracy or integrity of any part of the work are appropriately investigated and resolved.

Chinzon D: acquisition, analysis, or interpretation of data for the work; revising it critically for important intellectual content; final approval of the version to be published; agreement to be accountable for all aspects of the work in ensuring that questions related to the accuracy or integrity of any part of the work are appropriately investigated and resolved.

Roveda F: acquisition, analysis, or interpretation of data for the work; revising it critically for important intellectual content; final approval of the version to be published; agreement to be accountable for all aspects of the work in ensuring that questions related to the accuracy or integrity of any part of the work are appropriately investigated and resolved.

Lobão Neto AA: acquisition, analysis, or interpretation of data for the work; revising it critically for important intellectual content; final approval of the version to be published; agreement to be accountable for all aspects of the work in ensuring that questions related to the accuracy or integrity of any part of the work are appropriately investigated and resolved.

Zaterka S: acquisition, analysis, or interpretation of data for the work; revising it critically for important intellectual content; final approval of the version to be published; agreement to be accountable for all aspects of the work in ensuring that questions related to the accuracy or integrity of any part of the work are appropriately investigated and resolved.

\section{Orcid}

Joaquim Prado P Moraes-Filho: 0000-0003-1280-6047.

Gerson Domingues: 0000-0003-0431-451X.

Decio Chinzon: 0000-0003-3030-6687.

Fabiana Roveda: 0000-0003-2898-717X.

Abner Augusto Lobão Neto: 0000-0003-2969-6796.

Schlioma Zaterka: 0000-0002-2260-9146.

Moraes-Filho JPP, Domingues G, Chinzon D, Roveda F, Lobão Neto AA, Zaterka S. Impacto da pirose e regurgitação no bem-estar de indivíduos da população geral: um inquérito nacional brasileiro. Arq Gastroenterol. 2021;58(1):5-9.

RESUMO - Contexto - Pirose e regurgitação ácida são sintomas típicos usualmente relacionados à doença do refluxo gastroesofágico (DRGE). A DRGE é um dos diagnósticos gastrointestinais com maior prevalência mundial, afetando significativamente a qualidade de vida dos pacientes. Objetivo - Analisar o impacto de sintomas relacionados à DRGE em uma amostra da população brasileira urbana. Métodos - Inquérito nacional via telefone com indivíduos brasileiros em contexto comunitário. O inquérito foi conduzido entre 6 de agosto e 12 de setembro de 2018 . A prevalência autorrelatada e a frequência dos sintomas foram avaliadas. Os respondentes classificaram o impacto dos sintomas no seu bem-estar geral utilizando uma escala numérica de 1 a 10 (1 = ausência de impacto; 10 = impacto muito grave, impedindo a pessoa de comer ou realizar atividades da vida diária). Análises estatísticas descritivas e bivariadas foram conduzidas. Resultados - A amostra final foi constituída por 1.773 indivíduos, 935 (52,7\%) mulheres, com idade média de 40 anos. A prevalência de pirose e regurgitação nos últimos 6 meses foi de 26,2\% ( $n=466)$ e 11,0\% ( $n=196$ ), respectivamente. Sexo feminino (pirose $n=266,28,5 \%$ e regurgitação $n=119,12,7 \%)$ apresentou prevalência mais alta do que o masculino $(n=200,23,1 \%$ e $n=78$, $8,9 \%$, respectivamente) $(P<0,05)$. Pirose na última semana foi relatada por 175 indivíduos $(9,8 \%)$, enquanto episódios de regurgitação por $67(3,8 \%)$. Ausência de impacto dos sintomas no bem-estar geral dos indivíduos foi observada para 82 respondentes $(17,6 \%)$ com pirose e $18(9,2 \%)$ daqueles com regurgitação. Impacto muito grave foi reportado por $46(9,8 \%)$ indivíduos com pirose e $41(20,9 \%)$ com regurgitação. Sexo feminino foi mais afetado pelos sintomas do que o masculino. Conclusão - Pirose e regurgitação foram bastante frequentes sendo o sexo feminino mais afetado. Tais sintomas levaram a impacto no bem-estar dos indivíduos, com maior prejuízo para mulheres.

DESCRITORES - Refluxo gastroesofágico. Azia. Qualidade de vida. Prevalência. Sinais e sintomas. Inquéritos e questionários. 


\section{REFERENCES}

1. Hunt R, Chen M, Melo AC, Ford A, Lazebnik L, Lizarzabal M, et al. World Gastroenterology Organisation Global Guidelines: GERD Global Perspective on Gastroesophageal Reflux Disease. J Clin Gastroenterol. 2017;51:467-78.

2. Bruley Des Varannes S, Marek L, Humeau B, Lecasble M, Colin R. Gastroesophageal reflux disease in primary care. Prevalence, epidemiology and Quality of Life of patients. Gastroenterol Clin Biol. 2006;30:364-70.

3. Eslick GD, Talley NJ. Gastroesophageal reflux disease (GERD): risk factors, and impact on quality of life-a population-based study. J Clin Gastroenterol. 2009;43:111-7.

4. Peery AF, Crockett SD, Barritt AS, Dellon ES, Eluri S, Gangarosa LM, et al. Burden of Gastrointestinal, Liver, and Pancreatic Diseases in the United States. Gastroenterology. 2015;149:1731-1741.e3.

5. Almario CV, Ballal ML, Chey WD, Nordstrom C, Khanna D, Spiegel BMR. Burden of Gastrointestinal Symptoms in the United States: Results of a Nationally Representative Survey of Over 71,000 Americans. Am J Gastroenterol. 2018;113:1701-10.
6. Moraes-Filho JPP, Chinzon D, Eisig JN, Hashimoto CL, Zaterka S. Prevalence of heartburn and gastroesophageal reflux disease in the urban Brazilian population. Arq Gastroenterol. 2005;42:122-7.

7. Oliveira SS, Santos IS, Silva JFP, Machado EC. [Gastroesophageal reflux disease: prevalence and associated factors]. [Article in Portuguese]. Arq Gastroenterol. 2005;42:116-21.

8. Associação Brasileira de Empresas de Pesquisa. Critério de Classificação Econômica Brasil 2015 [Internet]. ABEP. 2015 [cited 2019 Jun 18]. Available from: www.abep.org/Servicos/Download aspx?id=09\&p=cb

9. Soares RLS, Costa MC, Saad MAN, Salles MMS, Paes J, Menezes GM. Prevalence of Normal Endoscopic Findings in Women with Dyspeptic Symptoms in a Brazilian Community. Ann Clin Exp Metab. 2017;2:1024.

10. Eusebi LH, Ratnakumaran R, Yuan Y, Solaymani-Dodaran M, Bazzoli F, Ford AC. Global prevalence of, and risk factors for, gastro-oesophageal reflux symptoms: a meta-analysis. Gut. 2018;67:430-40. 